\title{
Spraakdiskriminasie by Bejaarde Gehoorapparaatgebruikers
}

\author{
Liza van Wyk, Isabel Uys en Maggi Soer
}

Departement Kommunikasiepatologie, Universiteit van Pretoria

\begin{abstract}
OPSOMMING
In hierdie studie is die invloed van veroudering op die spraakdiskriminasievermoë van bejaarde gehoorapparaatgebruikers ondersoek. 'n Opname-metode is gebruik en dertig proefpersone, met dieselfde graad van perifere gehoorafname, is in twee groepe van vyftien persone elk verdeel. Groep 1 het bestaan uit bejaarde gehoorapparaatgebruikers wat geen of geringe spraakdiskriminasieprobleme ervaar, terwyl Groep 2 ernstige spraakdiskriminasieprobleme ervaar. ' $n$ Verskeidenheid toetse, naamlik die Sintetiese Sinsidentifikasietoets, die Verspringende Spondeewoordtoets en die aanbieding van monosillabiese woorde tesame met 'n ipsi-kompeterende spraakboodskap, is gebruik om hul spraakdiskriminasievermoë in verskillende luistersituasies te bepaal. ' $n$ Selfevaluasieskaal is ook deur die bejaardes voltooi. Die resultate van hierdie studie toon dat die verouderingsproses en die effek hiervan op veral sentrale ouditiewe prosessering, bydra tot die kompleksiteit en uiteenlopendheid van bejaarde gehoorapparaatgebruikers se spraakdiskriminasieprobleme. Die resultate beklemtoon verder die noodsaaklikheid van volledige intervensieprogramme vir bejaarde gehoorapparaatgebruikers.
\end{abstract}

\begin{abstract}
This study investigates the influence of aging on the speech discrimination abilities of elderly hearing instrument users. $A$ survey method was used and thirty subjects, with the same degree of peripheral hearing loss, were divided into two groups of fifteen persons each. Group 1 consisted of elderly hearing instrument users who experienced little or no speech discrimi. nation problems while group 2 consisted of persons with severe speech discrimination problems. The Synthetic Sentence Identification test, the Staggered Spondaic Word test and phonemically balanced words with an ipsi-competitive speech noise, were used to ascertain their speech discrimination capabilities in different listening situations. The elderly also completed a self-evaluation scale. The results of the study indicate that the aging process and changes in central auditory processing contribute to the complexity and diversity of elderly hearing instrument user's speech discrimination problems. The results also stress the importance of comprehensive intervention programmes for elderly hearing instrument users.

SLEUTELWOORDE: spraakdiskriminasie, bejaarde gehoorapparaatgebruikers, sentrale ouditiewe prosessering.

Die verouderingsproses blyk die dominante oorsaak van gehoorprobleme by bejaardes té wees (Working Group on Speech Understanding and Aging, 1988). Histopatologiese en morfologiese studies bevestig veranderinge in die totale gehoorsisteem wat die perifere gehoormeganisme, die koglea, gehoorsenuwee, breinstam en die temporale lobbe insluit (Willott, 1991). Hierdie ouderdomsverwante veranderinge in die ouditiewe sisteem kan ouditief presenteer as 'n perifere gehoorverlies, 'n sentrale ouditiewe prosesseringsprobleem of as 'n kombinasie van die twee verskynsels. 'n Verskeidenheid ander faktore kan ook gekoppel word aan die gehoor- en spraakdiskriminasieprobleme wat bejaardes ervaar. Metaboliese veranderinge, vaskulêre abnormaliteite, nierprobleme, medikasie, bepaalde mediese behandeling en geraasblootstelling kan ook die gehoor van die bejaarde beïnvloed (Willott, 1991). Bepaalde faktore soos neuro-anatomiese veranderinge as gevolg van die verouderingsproses,

degenerasie van bepaalde kognitiewe funksies soos geheue, a andag, spoed van prosessering en ook linguistiesouditiewe funksies blyk 'n negatiewe invloed op die totale ouditiewe prosesseringsvermoë van die bejaarde te hê (Lemme \& Hedberg, 1988; Marshall, 1981; Cohen, 1987 \& Willott, 1991).

Die passing van gehoorapparate word beskou as 'n primêre rehabilitasiestrategie om gehoorgestremde bejaardes se gehoor te verbeter (Hull, 1985). 'n Groot persentasie van die bejaarde gehoorapparaatgebruikers ervaar egter steeds probleme met kommunikasie en veral met spraakdiskriminasie in die teenwoordigheid van agtergrondgeraas, ten spyte van klankversterking (Stach, 1994). Hierdie probleme presenteer egter nie in dieselfde mate by gehoorapparaatgebruikers met dieselfde graad van perifere gehoorafname nie (Stach, 1994; Hull, 1985).

Spraakdiskriminasieprobleme is in die verlede veral toegeskryf aan die afname in perifere gehoorsensitiwiteit
\end{abstract}


(Jerger, Jerger, Oliver \& Pirozzolo, 1989; Humes \& Roberts, 1990). Resente navorsing dui egter daarop dat die ouderdomsverwante veranderinge in die sentrale ouditiewe sisteem ook tot spraakdiskriminasieprobleme kan bydra (Rodriguez, DiSarno \& Hardiman, 1990; Jerger, et al., 1989; Marshall, 1981). 'n Kombinasie van die effek van 'n perifere gehoorverlies en die afname in sentrale ouditiewe prosessering is nie uitgesluit nie (Willott, 1991). Daar is dus geen uitsluitsel oor die ware aard en oorsake van spraakdiskriminasieprobleme soos wat dit presenteer by bejaardes nie, maar die betrokkenheid van die sentrale ouditiewe sisteem geniet toenemende aandag in die jongste navorsingsliteratuur (Rodriguez, et al., 1990; Jerger, et al., 1989). Klem word tans ook veral geplaas op die gebruik van sentrale spraaktoetse om sentrale ouditiewe funksionering te evalueer (Stach, 1994).

Die motivering vir hierdie studic word gerig deur bepaalde kontroversies, leemtes en 'n behoefte aan kennis oor gehoorprobleme en veral spraakdiskriminasieprobleme soos wat dit presenteer by die bejaarde en veral by die bejaarde gehoorapparaatgebruiker. Vanweë die kompleksiteit van die bejaarde se ouditiewe probleme bestaan daar ook leemtes ten opsigte van die toetsing, diagnose en rehabilitasic van die bejaarde met gehoorprobleme. Hierdie leemtes en 'n behoefte aan meer kennis van die bejaarde se unieke ouditiewe probleme moet dus aangespreek word.

\section{METODE}

\section{$D O E L$}

Die hoofdoelstellings van hierdie studie is om die invloed van veroudering op die spraakdiskriminasievermoë van bejaarde gehoorapparaatgebruikers, met dieselfde graad van perifere gehoorverlies, te ondersoek en om te bepaal waarom sommige bejaarde gehoorapparaatgebruikers meer probleme met spraakdiskriminasie ondervind as ander (Van Wyk, 1997).

Die hoofdoelstellings word gerealiseer in dic volgende subdoelstellings:

1. Om spraakdiskriminasie in stilte van twee groepe bejaardes, naamlik bejaardes met geringe spraakdiskriminasieprobleme en bejaardes met ernstige spraakdiskriminasieprobleme, te bepaal en te vergelyk.

2. Om die spraakdiskriminasievermoë van die twee genoemde groepe in komplekse luistersituasies te bepaal en te vergelyk.

3. Om die twee groepe bejaardes se subjektiewe ervaring van hul gehoorprobleme en die baat wat hul vind by die dra van gehoorapparate te bepaal en te vergelyk.

4. Om te bepaal of daar ' $n$ verband is tussen die twee groepe se subjektiewe evaluasie van hul gehoorprobleme (sonder gehoorapparate) en die objektiewe oudiologiese evaluering van hul perifere gehoorstatus.

5. Om te bepaal of daar ' $n$ korrelasie is tussen die bejaardes se subjektiewe evaluasie van hul gehoorfunksionering en die objektiewe meting van hul spraakdiskriminasievermoë in verskillende luistersituasies.

\section{NAVORSINGSONTWERP}

Die bepaalde navorsingstrategie wat in hierdie studie gebruik is, is die opname-metode (Jacobs, Haasbroek \& Theron, 1992). Die kwalitatiewe-kwantitatiewe aard van hierdie navorsing verseker die realisering van die doelstellings (Jacobs, et al., 1992).

\section{PROEFPERSONE}

Dertig bejaardes is op ' $n$ afhanklike, ewekansige wyse geselekteer en in die twee navorsingsgroepe verdeel (Jacobs, et al., 1992). Die proefpersone het aan dic volgende kriteria voldoen:

1. Afrikaans moet die moedertaal wees, aangesien alle toetsstimuli in Afrikaans aangebied is. Navorsing toon dat sentrale toetse wat nie in die kliënt se moedertaal aangebied word nic, aanleiding kan gee tot swakker resultate wat nie net verklaarbaar is op grond van sentrale ouditiewe funksionering nie (Lemme \& Hedberg, 1988).

2. Persone vanaf 65 jaar word vir die doeleindes van hierdie studie beskou as bejaard en is dus ingesluit. Ouderdomme wissel tussen 65-90 jaar. Deur die insluiting van bejaardes oor die totale ouderdomspektrum kan bepaal word of daar' $n$ verband is tussen veroudering en die mate waarin spraakdiskriminasieprobleme voorkom (Willott, 1991).

3. Sowcl mans as vrouens is geselekteer, om te verseker dat spraakdiskriminasie by die bejaarde populasie, soos wat hulle in die samelewing leef, ondersoek word (Marshall, 1981).

4. Normale middeloorfunksionering is 'n vereiste om sodoende te verseker dat dit nie 'n invloed op die perifere gehoorstatus van die bejaardes het nie (Margolis \& Shanks, 1985).

5. Bejaardes met binourale, geringe tot gemiddelde, sensories-neurale hoëfrekwensie-gehoorverliese is geselekteer. Hierdie oudiometriese konfigurasic is kenmerkend van presbikusie (Willott, 1991). Dit impliseer gehoorverliese waarvan die gemiddelde suiwertoondrempels (by $500 \mathrm{~Hz}, 1000 \mathrm{~Hz}$ en $2000 \mathrm{~Hz}$ ) $>25 \mathrm{~dB}$ en $<56 \mathrm{~dB}$ is (Yantis, 1994). Vir hierdie studie is bejaardes met gemiddelde suiwertoondrempels van $40 \mathrm{~dB}-50 \mathrm{~dB}$ geselekteer om eenvormigheid te verseker. Die hoër frekwensies is ook in ag geneem, aangesien hierdie gehoordrempels ' $n$ belangrike invloed op spraakdiskriminasie het. Drempels tussen ongeveer $50 \mathrm{~dB}-70 \mathrm{~dB}$ by $4000 \mathrm{HZ}$ en $60 \mathrm{~dB}-80 \mathrm{~dB}$ by $8000 \mathrm{~Hz}$ is aanvaar en dit pas in by die beskrywing van presbikusie (Willott, 1991).

6. Bejaardes se mediese geskiedenis móet vry wees van enige serebro-vaskulêre insidente, seniliteit en enige geslotehoofbeserings of enige ander siektetoestand, aangesien dit moontlik 'n negatiewe invloed op die toetsresultate kan hê (Willott, 1991). Die bejaardes mag ook geen ototoksiese middels of enige ander medikasie gebruik wat 'n remmende invloed op die werking van die sentrale senuweesisteem kan hê nie (Rodriguez et al., 1990; Jerger et al., 1989; Marshall, 1981).

7. Alle proefpersone is aan ' $n$ siftingsprosedure onderwerp, om te bepaal of kognitiewe en ook linguistiese vaardighede intakt is, aangesien hierdie faktore ook die spraakdiskriminasievermoë kan beïnvloed. (Cohen, 1987; Lemme \& Hedberg, 1988).

Die volgende materiaal en apparaat is gebruik om die dertig bejaardes vir hierdie studie te selekteer (Van Wyk, 1997): 
'n Gevalgeskiedenisvorm is gebruik, om identifiserende inligting en ook ander inligting soos die mediese geskiedenis, aanvang van gehoorverlies en kommunikasieprobleme, op te teken (Rosenberg, 1978);

- Die Mini Mayo Mental Scale is gebruik om kognitiewe funksionering te evalueer (Folstein, Folstein \& McHugh, 1975);

- Subtoetse van die Bostonse Diagnostiese Afasietoets is gebruik om linguistiese vermoë te evalueer (Goodglass \& Kaplan, 1983);

- Alle oudiometriese toetsing is met'n GSI 16-oudiometer uitgevoer en voldoen aan die vereiste van die SABS 0154-1983 (Suid-Afrikaanse Buro vir Standaarde, 1994). Die oudiometer is geyk op 1995-01-04. TDH-50Poorfone, gemonteer in MX-51-kussings is vir suiwertoonoudiometrie gebruik. ' $\mathrm{n}$ B-17-Beengeleier is vir beengeleidingstoetse gebruik. Toetse is in 'n klankdigte kamer van Industrial Acoustics Company Inc. uitgevoer en die toetsomgewing voldoen aan die SABS 0182-1982standaard (Suid-Afrikaanse Buro vir Standaarde, 1994). 'n GSI-33-Middelooranaliseerder is gebruik om immittansietoetsing uit te voer.

- 'n Heine Alpha Nica Tron 2-otoskoop is gebruik om die otoskopiese ondersoek op die proefpersone uit te voer.

Bejaarde gehoorapparaatgebruikers, wat die Phonakgehoorsentrum (Pretoria) tussen Januarie 1993 en Januarie 1995 besoek het, is tydens die seleksie van proefpersone genader. Bejaardes wat hul gehoorapparate daagliks vir ongeveer twee jaar gedra het, is geselekteer vir die studie. Sodoende is verseker dat bejaardes reeds aangepas het by die dra van gehoorapparate en is eenvormigheid ten opsigte van klankversterking verseker. Op grond van die bejaardes se suiwertoondrempels en subjektiewe evaluasie van hul gehoorprobleme is dertig bejaardes op 'n afhanklike, ewekansige wyse vanuit 'n totale populasie van 485 bejaardes geselekteer en in twee groepe verdeel, naamlik bejaardes met geen of geringe spraakdiskriminasieprobleme en bejaardes met ernstige spraakdiskriminasieprobleme. Sowel Groep 1 as Groep 2 het bestaan uit sewe vrouens en agt mans. Die dertig persone is telefonies gekontak waartydens'n afspraak vir 'n konsultasie gemaak is.

Tydens ' $n$ konsultasie is 'n gestruktureerde onderhoud gebruik om 'n volledige gevalgeskiedenis van die bejaardes te verkry en die kognitiewe en linguistiese vaardighede is ook geëvalueer. 'n Otoskopiese ondersoek is op elke proefpersoon voor die oudiologiese toetsing uitgevoer. 'n Timpanogram is van elke proefpersoon verkry en elke proefpersoon moes aan die gestelde norme voldoen soos bespreek in die literatuur om as proefpersoon geselekteer te word (Margolis \& Shanks, 1985), 'n Volledige suiwertoonoudiogram is verkry, spraakontvangsdrempelbepaling en spraakdiskriminasietoetsing in stilte is ook uitgevoer (Van Wyk, 1997). Die uitvoering van hierdie prosedures stem ooreen soos bespreek in bestaande litératuur (Van Wyk, 1997; Yantis, 1994; Penrod, 1994).

Tabel 1 verskaf 'n opsomming van die eienskappe van die dertig proefpersone wat vir hierdie studie gebruik is (Van Wyk, 1997).

\section{MATERIAAL EN APPARAAT}

Die materiaal en apparaat wat in hierdie studie gebruik is, word in twee onderafdelings bespreek, naamlik:

\section{A. Materiaal en apparaat gebruik vir die insameling} van data

Die volgende apparaat is tydens die insameling van data gebruik (Van Wyk, 1997):

- Die GSI 16-oudiometer (geyk op 1995-01-04) is ook gebruik tydens die uitvoering van spesiale spraaktoetse. Alle toetse is in dieselfde klankdigte kamer uitgevoer soos reeds voorheen gespesifiseer. 'n Tweekanaalbandopnemer, naamlik 'n Marantz Stereo Cassette Deck SD-255, is aan die gespesifiseerde oudiometer gekoppel vir die uitvoer van die spraaktoetse. 'n Hoëkwaliteit TDK D90-kasset is gebruik vir die opneem van die kompeterende boodskap, die onsinsinne en ook die digotiese toetsprosedure, wat gebruik is tydens die uitvoering van die komplekse spraaktoetse.

Tabel 2 verskaf 'n oorsig van en motivering vir die verskillende toetse en materiaal wat tydens die studie gebruik is: die siftings-, die basiese en ook die spesiale sentrale-toetse, asook die selfevaluasieskaal.

\section{B. Materiaal vir die optekening en verwerking van data}

Response van die proefpersone in die verskillende toetse, is op bestaande responsvorms, wat in die kliniese opset gebruik word, opgeteken (Van Wyk, 1997). Statistiese verwerkings is gedoen met behulp van 'n IBM 370rekenaar en die Statistical Packages for Social Sciences program, Universiteit van Pretoria (Theron, 1995).

\section{DATAVERSAMELINGSPROSEDURES}

Die volgende dataversamelingsprosedures is in hierdie studie gevolg en word in twee onderafdelings bespreek, naamlik:

\section{A. Dataversamelingsprosedures wat uitgevoer is tydens die navorsing}

Alle spraaktoetse en spesiale toetse is uitgevoer deur gebruik te maak van bandopnames. Sodoende is verseker dat die aanbieding van toetse op 'n konstante wyse plaasgevind het en is die toetsgeldigheid en -betroubaarheid verhoog (Penrod, 1994).

Spraakdiskriminasietoetsing in stilte is uitgevoer by $50 \mathrm{~dB}, 40 \mathrm{~dB}, 30 \mathrm{~dB}, 20 \mathrm{~dB}$ en $10 \mathrm{~dB}$ bokant die spraakontvangsdrempel. By $50 \mathrm{~dB}$ bokant die spraakontvangsdrempel is bepaal of 'n "rollover" voorkom (Penrod, 1994).

- Die Sintetiese Sinsidentifikasietoets is by dieselfde aanbiedingsintensiteit as bogenoemde uitgevoer ten einde die verskillende resultate met mekaar te vergelyk (Kaplan, et al., 1984; Van Wyk, 1997; Willeford, 1985).

- Die Verspringende Spondeewoordtoets is so aangebied dat die proefpersone die spondeewoorde in die RegsNie-Kompeterende (R-N-K); Regs-Kompeterende (R-K); Links-Kompeterende (L-K) en Links-Nie-Kompeterende (L-N-K) luistersituasies moes herhaal (Kaplan, et al., 1984). Die toets is by $40 \mathrm{~dB}$ bokant die gemiddelde suiwertoondrempels by $500 \mathrm{~Hz}, 1000 \mathrm{~Hz}$ en $2000 \mathrm{~Hz}$ aangebied (Lukas \& Genchur-Lukas, 1985).

- Die monosillabiese woorde tesame met die ipsi- 


\begin{tabular}{|c|c|c|c|c|}
\hline 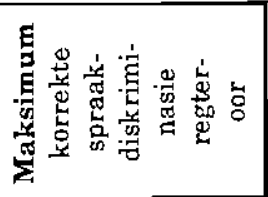 & 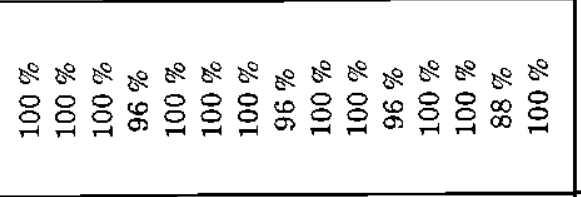 & $\begin{array}{l}\therefore \\
\vdots \\
\infty \\
\infty\end{array}$ & 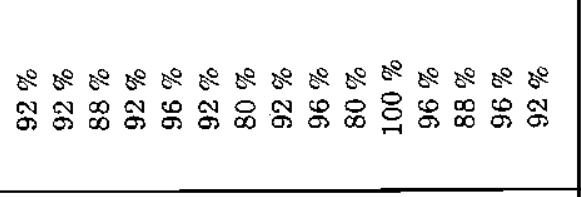 & $\frac{\pi}{2}$ \\
\hline 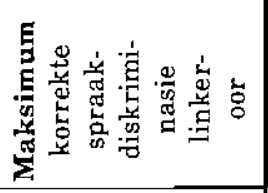 & 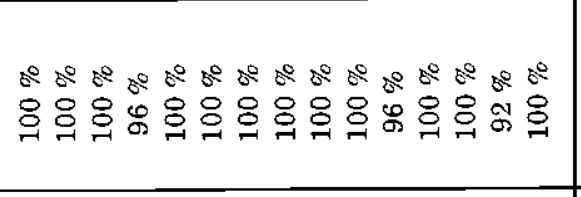 & $\begin{array}{l}\therefore \\
\infty \\
\infty \\
\infty\end{array}$ & 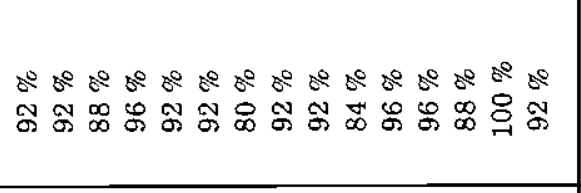 & $\frac{\pi}{6}$ \\
\hline 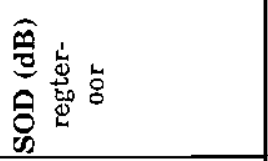 & 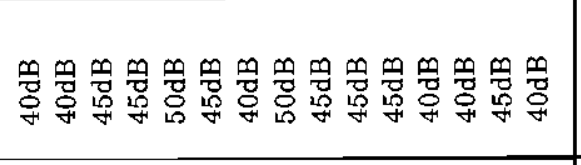 & 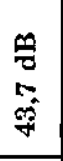 & 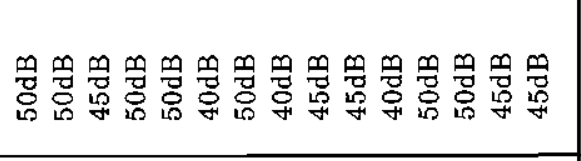 & 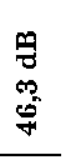 \\
\hline 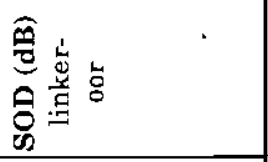 & 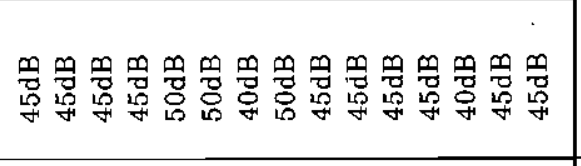 & 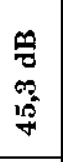 & 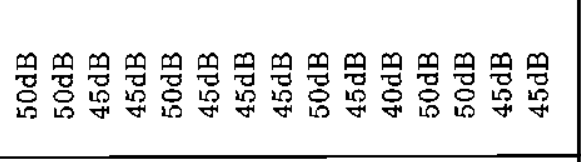 & 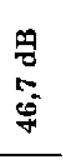 \\
\hline 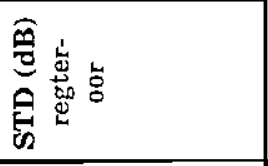 & 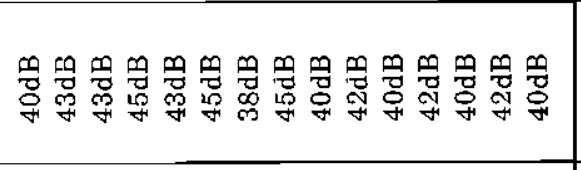 & \begin{tabular}{l}
$\mathscr{\varphi}$ \\
\multirow{2}{*}{} \\
ปั
\end{tabular} & 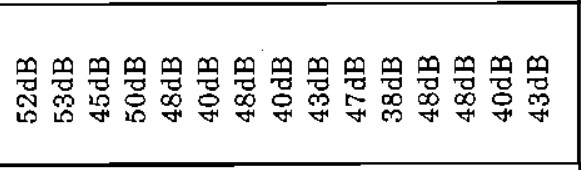 & 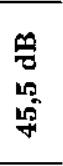 \\
\hline 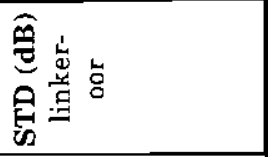 & 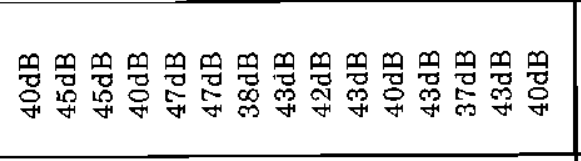 & 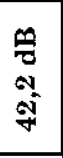 & 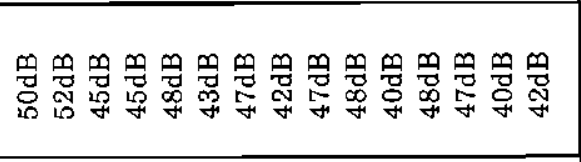 & 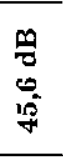 \\
\hline 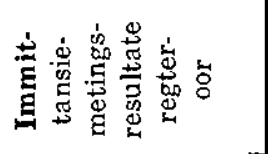 & 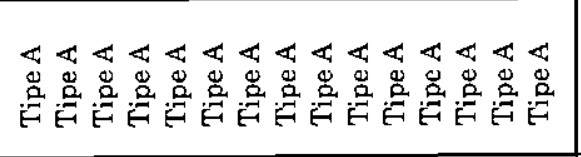 & & 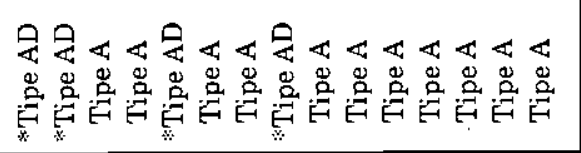 & \\
\hline 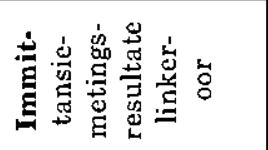 & 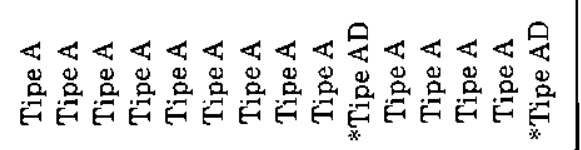 & & 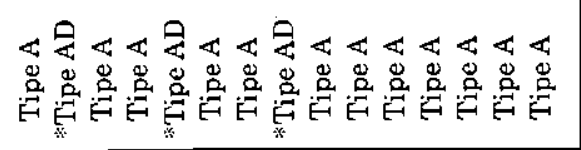 & \\
\hline 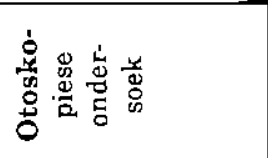 & 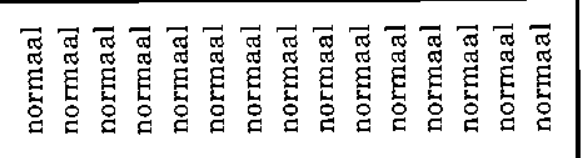 & & 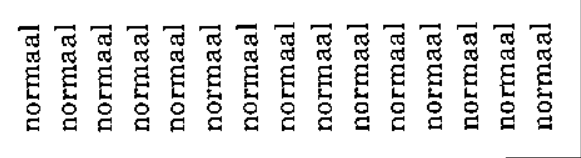 & \\
\hline 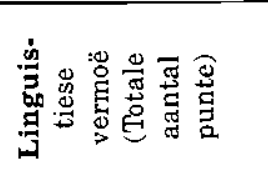 & 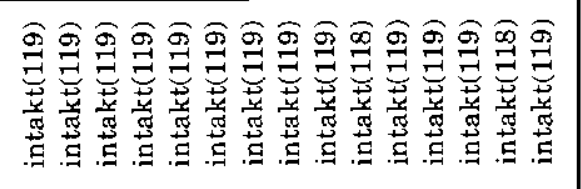 & $\stackrel{\substack{\infty \\
=}}{\Rightarrow}$ & 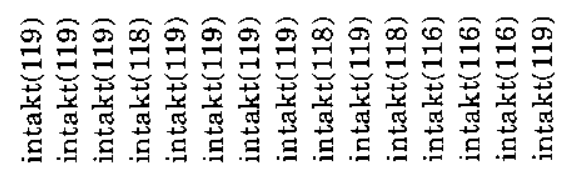 & $\stackrel{\infty}{\infty} \underset{\infty}{=}$ \\
\hline 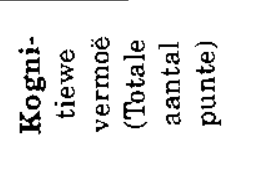 & 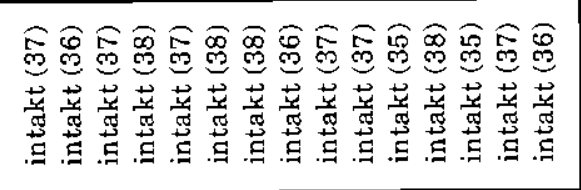 & $\begin{array}{l}\infty \\
\stackrel{\infty}{0}\end{array}$ & 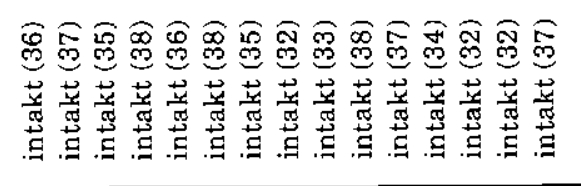 & : \\
\hline 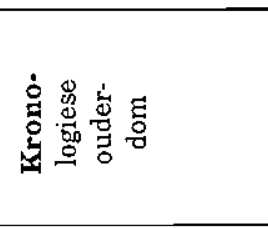 & 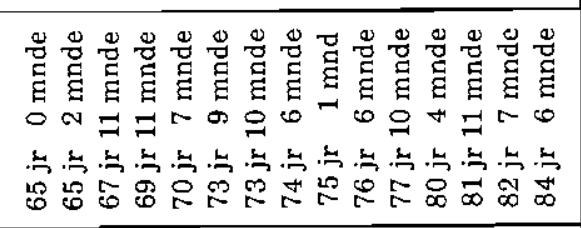 & 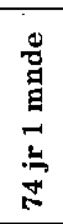 & 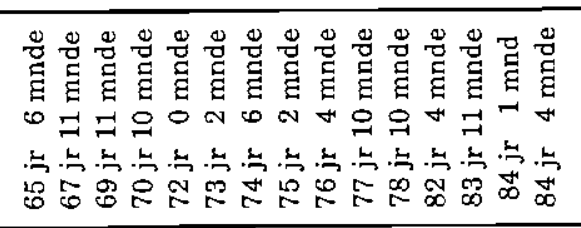 & 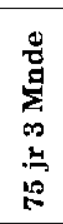 \\
\hline $\begin{array}{l}\text { so } \\
\frac{\pi}{6} \\
0 \\
0\end{array}$ & $>\Sigma>\Sigma>\Sigma>\Sigma>\Sigma \Sigma>>\Sigma \Sigma$ & & $P \Sigma>\Sigma>\Sigma \Sigma \Sigma D \Sigma \Sigma \Sigma D>P$ & \\
\hline 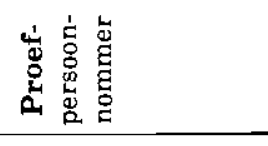 & オN" & & 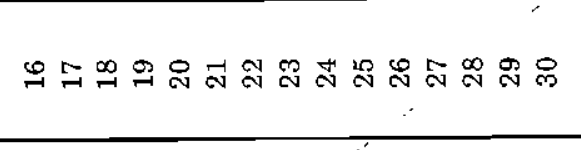 & \\
\hline 量 & $\rightarrow$ & 离 & a & 离 \\
\hline
\end{tabular}


TABEL 2: Oorsig van die verskillende toetse

\begin{tabular}{|lll|}
\hline Toetse & Motivering vir keuse van toetse & Verwysing \\
\hline 1. SIFTINGSTOETSE & & \\
\hline * Mini Mayo Mental & $\begin{array}{l}\text { Dien as siftingsinstrument om kognitiewe vaardighede } \\
\text { soos oriëntasie, aandag, lees, leer, rekenkunde, } \\
\text { abstraksie en algemene kennis te evalueer. }\end{array}$ & Folstein, et al., 1975 \\
* Bostonse Diagnostiese \\
Afasietoets & $\begin{array}{l}\text { Dien as siftingsinstrument om linguistiese vaardighede } \\
\text { soos, woordvindingsvermoë, ouditiewe begrip en verbale } \\
\text { uitdrukkings te evalueer. }\end{array}$ & $\begin{array}{c}\text { Goodglass \& Kaplan, } \\
1983\end{array}$ \\
\hline
\end{tabular}

\section{BASIESE TOETSBATTERY}

* Gevalgeskiedenis

* Otoskopiese ondersoek

* Suiwertoonoudiogram (lug- en beengeleiding)

* Spraakontvangsdrempel (SOD)

* Spraakdiskriminasie in stilte

* Akoestiese Immittansiemeting
Bevat identifiscrende inligting van bejaarde, asook inligting soos, aanvang van gehoorverlies, simptome, oorsake, mediese geskiedenis en kommunikasievaardighede.

Evalueer status van eksterne oorgedeelte, oorkanaal en timpaniese membraan.

Bepaal luggeleidingsdrempels by $125 \mathrm{~Hz}-8000 \mathrm{~Hz}$ en beengeleidingsdrempels by $250 \mathrm{~Hz}-4000 \mathrm{~Hz}$ ten einde die graad en aard van die perifere gehoorverlies te bepaal.

Ingesluit om te bepaal waar proefpersone $50 \%$ van spondeewoorde kan identifiseer. Dien ook as basis waarvolgens die intensiteit vir aanbieding van ander toetsstimuli bepaal word en om STD te kontroleer.

Bepaal spraakdiskriminasievermoë in stilte om die spraakdiskriminasie kurwe te verkry waar bejaardes hul FG-maksimum en $50 \%$ korrekte spraakdiskriminasie behaal.

Evalueer middeloorfunksionering om onder andere die statiese beweeglikheid en fisiese volume te bepaal

Rosenberg, 1978

Yantis, 1994

Yantis, 1994

Penrod, 1994

Penrod, 1994

Laubscher \& Tesner, 1996

Margolis \& Shanks, 1985

\section{SPESIALE SENTRALE-TOETSE}

* Sintetiese Sins-

* Verspringende Spondeewoordtoets (VSW-toets)

* Monosillabiese woorde en die aanbieding van 'n ipsi-kompeterende boodskap
Evalueer sentrale ouditiewe funksie en spraakdiskriminasievermoë. Differensiale diagnostiese toets om te onderskei tussen kogleêre, retro-kogleêre en sentrale letsel.

Evalueer spraakdiskriminasievermoë in onder andere, komplekse luistersituasies en kompenseer vir die perifere gehoorverlies.

Identifiseer spraakdiskriminasieprobleme tydens die aanbieding van 'n ipsi-kompeterende boodskap (sein-tot-ruis-verhouding $:+5 \mathrm{~dB}$ )
Jerger, et al., 1989

Kaplan, et al,, 1984

Willeford, 1985

Muller, 1981

Kaplan, et al., 1984

Lukas \& GenchurLukas, 1985

Penrod, 1994

Stach, 1994

\section{SELF-EVALUASIESKAAL}

* "Hearing Handicap

Inventory for the

Elderly" (HHIE)
Subjektiewe inligting deur die bejaarde verskaf wat aanvullend is tot die objektiewe oudiometriese data; Evalueer situasie- en emosionele veranderlikes van 'n gehoorverlies wat 'n invloed kan hê op alledaagse funksionering;

Verskaf inligting oor evaluasie sonder en met gehoorapparate. 
kompeterende boodskap is aangebied $40 \mathrm{~dB}$ bokant die spraakontvangsdrempel. Die sein-tot-ruis-verhouding was $+5 \mathrm{~dB}$ (Penrod, 1994).

Die selfevaluasieskaal is twee keer tydens 'n gestruktureerde onderhoud voltooi. Tydens die eerste sessie het die proefpersone die skaal voltooi asof hulle nie gehoorapparate dra nie en die tweede keer is die skaal voltooi asof hulle gehoorapparate dra (Ventry \& Weinstein, 1982).

\section{B. Data-optekening-en dataverwerkingsprosedures}

Response van die 30 proefpersone is opgeteken op die verskillende responsvorms, soos reeds bespreek. Die dataoptekeningsprosedures, wat betref die resultate van die oudiometriese toetsing, stem ooreen met die optekeningsprosedures wat in die praktyk gebruik word. Al die relevante toetsresultate is vir elkeen van die 30 proefpersone opgeteken op 'n individuele responsvorm.

Tydens die analise en prosessering van die data is daar gebruik gemaak van beskrywende en nie-parametriese statistiek (Theron, 1995). Data is verwerk met'n IBM 370rekenaar en die Statistical Packages for Social Sciences program, Universiteit van Pretoria, (Theron, 1995). In Tabel 3 word'n opsomming van die statistiese prosedures verskaf wat gebruik is om elke subdoelstelling te beantwoord (Van Wyk, 1997).

\section{RESULTATE}

Tabel 4 bied 'n opsomming van die twee navorsingsgroepe se gemiddelde resultate op die verskillende toetse (Van Wyk, 1997). Dit blyk duidelik dat daar 'n beduidende verskil tussen die resultate van die twee groepe is, behalwe ten opsigte van die totale prestasie met en sonder gehoorapparate.

\section{SUIWERTOONRESULTATE VAN DIE BEJAARDES}

Die gemiddelde suiwertoondrempels vir Groep 1 is $42,2 \mathrm{~dB}$ vir beide ore. Groep 2 se gemiddelde suiwertoondrempels is $45,6 \mathrm{~dB}$ vir die linker- en $45,5 \mathrm{~dB}$ vir die regterore. Daar is dus nie ' $n$ beduidende verskil tussen die resultate van Groep 1 en Groep 2 op die 5\% vlak van beduidenheid nie. Daar is ook nie 'n beduidende verskil tussen die regter- en linkerore van elke groep afsonderlik nie $(p \leq 0,05)$.

\section{SPRAAKDISKRIMINASIEVERMÖ̈ IN STILTE}

Die maksimum-gemiddelde prestasie by $40 \mathrm{~dB}$ bo die spraakontvangsdrempel vir Groep 1 was $98,9 \%$ vir die linkerore en $98,4 \%$ vir die regterore. Die maksimumgemiddelde prestasie by dieselfde intensiteitsvlak vir Groep 2 was $91,5 \%$ vir beide ore. Groep 2 presteer beduidend swakker as Groep 1 by al die verskillende intensiteitsvlakke $(p \leq 0,05)$. ' $n$ Tweede afleiding is dat daar geen beduidende verskil tussen die linker-en regterore van elke groep afsonderlik vir die toets bestaan nic (Groep 1: $\mathrm{p}=0,1056$ en Groep 2: $\mathrm{p}=0,180$ ).

Daar is verder geen toename in spraakdiskriminasieprobleme, soos ouderdom toeneem nie. Daar is ook nie 'n beduidende verskil tussen die spraakdiskriminasieresultate van mans en vrouens nie ( $p=0,2049)$. Die "rollover-" fenomeen, in beide ore, is by drie bejaardes in Groep 2 geïdentifiseer.

\section{SPRAAKDISKRIMINASIEVERMÖ̈ IN KOMPLEKSE LUISTERSITUASIES}

Die resultate in die verskillende komplekse luistersituasies is soos volg:

\subsection{Prestasie in die Sintetiese Sinsidentifikasietoets}

Groep 1 se maksimum-gemiddelde prestasie is $68,0 \%$ in die linker- en $66,9 \%$ in die regterore. Groep 2 behaal $24,6 \%$ vir die linker- en $22,7 \%$ vir die regterore. Groep 2 presteer dus beduidend swakker as Groep 1 tydens die aanbieding en identifikasie van die sinne met'n sein-tot-ruisverhouding van $0 \mathrm{~dB}(\mathrm{p} \leq 0,05)$. Ander resultate dui daarop dat daar geen beduidende verskil tussen die prestasie van die linkeren regterore van elke groep se SSI-PI-funksie afsonderlik is nie (p-waarde vir Groep 1 is 0,1056 en vir Groep 2 is dit 0,2049 ). Die gemiddelde SSI-PI-funksie is vir beide groepe beduidend swakker as die FG-PI-funksie, maar Groep 2 (p $=0,000)$ se resultate wyk meer af as dié van Groep $1(\mathrm{p}=$ $0,0003)$. Die "rollover-" fenomeen, in beide ore, het voorgekom by sewe bejaardes in Groep 2 .

Die tweede diagnostiese prosedure van die SSI-toets is om die SSI-IKB-resultate met die SSI-KKB-resultate te vergelyk. Daar is 'n beduidende verskil tussen die SSIIKB-resultate van die twee groepe, waar die sein-tot-ruisverhouding $+10 \mathrm{~dB}, 0 \mathrm{~dB}$ en $-10 \mathrm{~dB}$ is. Die prestasie van Groep 2 is beduidend swakker as die prestasie van Groep 1 ( $p \leq 0,05)$. Met'n sein-tot-ruis-verhouding van $-20 \mathrm{~dB}$ was daar egter geen beduidende verskil tussen die twee groepe nie. Die SSI-KKB-resultate, met die sein-tot-ruisverhoudings $0 \mathrm{~dB},-20 \mathrm{~dB}$ en $-40 \mathrm{~dB}$, dui daarop dat Groep 2 beduidend swakker gevaar het as Groep 1. Daar is egter geen beduidende verskil tussen die linker- en regterore van elke groep se resultate afsonderlik nie ( $p=0,1474$ vir Groep 1 en vir Groep 2 is $p=0,2241$ ). SSI-IKB-afwykings is by albei groepe groter as SSI-KKB afwykings. Ander resultate is dat daar geen beduidende verskil tussen mans en dames se prestasie is nie $(\mathrm{p}=0,7938)$.

\subsection{Toetsresultate van die Verspringende Spondeewoordtoets}

Ten opsigte van die totale prestasie-korrekte dișkriminasie, behaal Groep 1, 56,7\% in die linker- en $82,7 \%$ in die regterore. Groep 2 behaal $36,1 \%$ in die linker- en $58,3 \%$ in die regterore. Na aanleiding van die $5 \%$-vlak $(\mathrm{p} \leq 0,05)$ van beduidenheid is daar' $n$ beduidende verskil tussen die twee groepe se prestasie in die vier verskillende luisteromstandighede (R-N-K; R-K; L-K en L-N-K). 'Dit geld vir sowel die Rou-VSW- en "Corrected"-VSW-resultate. Resultate toon verder dat daar nie 'n beduidende verskil tussen die R-VSW-en C-VSW-resultate van Groep 1 is nie $(p \leq 0,05)$. Vir Groep 2 is daar egter'n beduidende verskil tussen die R-VSW-en C-VSW-resultate by al vier die luisteromstandighede (vir R-N-K is $P=0,0004$; vir $R-K$ is $p=0,0004$; vir $\mathrm{L}-\mathrm{K}$ en $\mathrm{L}-\mathrm{N}-\mathrm{K}$ is $\mathrm{p}=0,0007$ ). Dit blyk dus dat Groep 2 beduidend meer probleme as Groep 1 in beide linker- en regteroor kompeterende situasies ondervind.

\subsection{Prestasie tydens die aanbieding van monosilla- biese woorde en 'n ipsi-kompeterende boodskap}

Die maksimum-gemiddelde prestasie vir Groep 1 se linkerore is $63,7 \%$ en vir die regterore $66,7 \%$. Die maksimum-gemiddelde prestasie vir Groep 2 is $48,3 \%$ vir 
TABEL 3:'n Opsomming van die verskillende statistiese prosedures wat gebruik is om elke subdoelstelling te beantwoord

\begin{tabular}{|c|c|c|}
\hline $\begin{array}{l}\text { SUBDOELSTELLINGS } \\
\text { PROSEDURES }\end{array}$ & BESKRYWING VAN STATISTIESE & VERWYSINGS \\
\hline $\begin{array}{l}\text { 1. Om die spraakdiskriminasievermoë } \\
\text { van die twee navorsingsgroepe in } \\
\text { stilte te bepaal en te vergelyk. }\end{array}$ & $\begin{array}{l}\text { 1.1 Die algemene liniêre metode is gebruik om } \\
\text { die rekenkundige gemiddelde vir elke } \\
\text { groep vir die verskillende toetsresultate } \\
\text { te bepaal; } \\
1.2 \text { Die Mann Whitney U-Wilcoxon Rank Sum } \\
\text { W- toets (5\% vlak van beduidenheid) is } \\
\text { gebruik om te bepaal of daar 'n beduidende } \\
\text { verskil tussen die resultate van die twee } \\
\text { groepe is. }\end{array}$ & $\begin{array}{l}\text { Theron, 1995; } \\
\text { Jacobs, et al., } \\
1992\end{array}$ \\
\hline $\begin{array}{l}\text { 2. Om die spraakdiskriminasievermoë } \\
\text { van die twee groepe in komplekse } \\
\text { situasies te bepaal en te vergelyk. }\end{array}$ & $\begin{array}{l}\text { 2.1 Die algemene liniêre metode is gebruik om } \\
\text { die rekenkundige gemiddelde prestasie van } \\
\text { elke groep in die verskillende toetse te bepaal; } \\
\text { 2.2 Die Mann Whitney U-Wilcoxon Rank Sum } \\
\text { W-toets ( } 5 \% \text { vlak van beduidenheid) is gebruik } \\
\text { om te bepaal of daar 'n beduidende verskil } \\
\text { tussen die resultate van die twee groepe is; } \\
\text { 2.3 Die Kendall en Spearman-toetse is gebruik } \\
\text { om te bepaal of daar'n beduidende korrelasie } \\
\text { tussen die resultate van die verskillende } \\
\text { spesiale spraaktoetse is. }\end{array}$ & $\begin{array}{l}\text { Theron, } 1995 . \\
\text { Theron, 1995; } \\
\text { Jacobs, et al., } \\
1992 . \\
\text { Theron, 1995; } \\
\text { Jacobs, et al., } \\
\text { 1992. }\end{array}$ \\
\hline $\begin{array}{l}\text { 3. Om die twee groepe se subjektiewe } \\
\text { ervaring van hul gehoorprobleme en } \\
\text { die baat wat hulle vind by die dra } \\
\text { van gehoorapparaat te bepaal en te } \\
\text { vergelyk. }\end{array}$ & $\begin{array}{l}\text { 3.1 Die algemene liniêre metode is gebruik om die } \\
\text { rekeningkundige gemiddelde vir die prestasie } \\
\text { met en sonder gehoorapparate te bepaal; } \\
\text { 3.2 Die Mann Whitney U-Wilcoxon Rank Sum } \\
\text { W-toets ( } 5 \% \text { vlak van beduidenheid) is gebruik } \\
\text { om te bepaal of daar'n beduidende verskil } \\
\text { tussen die resultate van die twee groepe is. }\end{array}$ & $\begin{array}{l}\text { Theron, 1995; } \\
\text { Jacobs, et al., } 1992 \\
\text { Theron, 1995; } \\
\text { Jacobs, et al., } 1992\end{array}$ \\
\hline $\begin{array}{l}\text { 4. Om te bepaal of daar'n korrelasie is } \\
\text { tussen die bejaardes se subjektiewe } \\
\text { evaluasie van hul gehoorprobleme } \\
\text { en die objektiewe oudiologiese } \\
\text { evaluering van hul perifere } \\
\text { gehoorstatus. }\end{array}$ & $\begin{array}{l}\text { 4.1. Die Kendall en Spearman toetse is gebruik om } \\
\text { te bepaal of daar'n beduidende korrelasie } \\
\text { tussen die resultate van die verskillende } \\
\text { spesiale spraaktoetse is. }\end{array}$ & $\begin{array}{l}\text { Theron, 1995; } \\
\text { Jacobs, et al., } \\
1992\end{array}$ \\
\hline $\begin{array}{l}\text { 5. Om te bepaal of daar 'n korrelasie is } \\
\text { tussen die bejaardes se subjektiewe } \\
\text { evaluering van hul gehoorfunk- } \\
\text { sionering en die objektiewe meting } \\
\text { van hulle spraakdiskriminasie- } \\
\text { vermoë. }\end{array}$ & $\begin{array}{l}\text { 5.1 Die Kendall en Spearman toetse is gebruik om } \\
\text { te bepaal of daar'n beduidende korrelasie } \\
\text { tussen die resultate van die verskillende } \\
\text { spesiale spraaktoetse is. }\end{array}$ & $\begin{array}{l}\text { Theron, 1995; } \\
\text { Jacobs, et al., } 1992\end{array}$ \\
\hline
\end{tabular}

TABEL 4: Opsomming van die verskillende toetsresultate

\begin{tabular}{|c|c|c|c|c|c|c|c|c|c|c|}
\hline \multirow[t]{2}{*}{$\begin{array}{l}\text { Gemiddelde } \\
\text { maksimum } \\
\text { Prestasie, } \\
(\%) \\
\text { Groep } 1\end{array}$} & \multicolumn{2}{|c|}{ FG-Maksimum } & \multicolumn{2}{|c|}{ SSI-Maksimum } & \multicolumn{2}{|c|}{ C-VSW } & \multicolumn{2}{|c|}{$\begin{array}{c}\text { Monosillabiese } \\
\text { woorde en 'n } \\
\text { ipsi-kompe- } \\
\text { terende } \\
\text { boodskap } \\
\text { L R R }\end{array}$} & \multicolumn{2}{|c|}{$\begin{array}{c}\text { HHLE- } \\
\text { (TOTAAL) }\end{array}$} \\
\hline & 98,9 & 98,4 & 68,0 & 66,0 & 56,7 & 82,7 & 63,7 & 66,7 & 56,3 & 76,8 \\
\hline Groep 2 & 91,5 & 91,5 & 27,7 & 22,6 & 36,1 & 58,3 & 48,3 & 48,5 & 50,9 & 65,2 \\
\hline \multicolumn{11}{|c|}{$\begin{array}{l}\text { - Vir vergelykingsdoeleindes is die C-VSW-tellings omgeskakel na persentasie korrek en dit is gebaseer op die } \\
\text { resultate van die kompeterende luistersituasies. } \\
\text { Die HHIE-prestasie is ook omgeskakel na die persentasie waarin geen probleme ondervind word nie en slegs die } \\
\text { totale tellings word aangetoon. }\end{array}$} \\
\hline
\end{tabular}


die linkerore en $48,5 \%$ vir die regterore. Op die $5 \%$-vlak van beduidenheid is Groep 2 se prestasies vir beide ore beduidend swakker as dić van Groep 1 (linkerore: $p=0,0011$; regterore: $p=0,0002$ ). Daar is egter nie 'n beduidende verskil tussen die prestasie van die linker- en regterore van elke groep afsonderlik nie (vir Grocp 1 is $p$ $=0,1501$; cn vir Groep 2 is $p=0,1378$ ). Groep 1 se waardes is hoër as $60 \%$ is en dui op geringe spraakdiskriminasieprobleme, terwyl Groep 2 se resultate beduidend swakker as $60 \%$ is en dit dan op ernstige spraakdiskriminasieprobleme dui $(\mathrm{p}=0,0353)$.

\section{DIE BEJAARDES SE SUBJEKTIEWE EVALUERING VAN HUL GEHOORPROBLEME}

Ten opsigte van die persentasie waarin die bejaardes geen probleme ondervind sonder en met gehoorapparate nie, behaal Groep 1 onderskeidelik $56,3 \%$ en $76,8 \%$. Groep 2 behaal $50,9 \%$ sonder gehoorapparate en $65,2 \%$ met gehoorapparate. Daar is dus ' $n$ beduidende verskil tussen die resultate van elke groep, afsonderlik, sonder en met hul gehoorapparate. Alle metings is uitgevoer op die $5 \%$ vlak van beduidenheid. Ten opsigte van Groep 1 se resultate is daar' $n$ beduidende verskil ( $p=0,0015$ ) op die totale prestasie met en sonder gehoorapparate. Groep 1 se bejaardes is dus van mening dat die gebruik van gehoorapparate 'n beduidende bydrae lewer tot dic kompensasie vir hul gehoorprobleme. Ook ten opsigte van die emosionele- $(p=0,0029)$ en die situasieveranderlikes ( $\mathrm{p}=0,0022$ ) is daar ' $\mathrm{n}$ beduidende verskil sonder en met gchoorapparate.

Groep 2 se resultate dui ook daarop dat die bejaardes beduidend baat vind by die dra van gehoorapparate. Net soos in die geval van Groep 1 is daar' $n$ beduidende verskil tussen die prestasie sonder en met gehoorapparate vir die totale prestasie $(p=0,0010)$ en ook die metings van die emosionele- $(\mathrm{p}=0,0022)$ en situasieveranderlikes $(\mathrm{p}=$ $0,0010)$.

Op die 5\%-vlak van beduidenheid is daar egter nie 'n beduidende verskil tussen die twee groepe se prestasie op die totale prestasie $(\mathrm{p}=0,6331)$, die emosionele- $(\mathrm{p}=$ 0,9834 ) en situasieveranderlikes ( $p=0,2889$ ) sonder gehoorapparate nie. Die afleiding kan dus gemaak word dat beide groepe bejaardes se subjektiewe evaluasie van hul gehoorprobleem ooreenstem. Ten opsigte van die evaluasie met hul gehoorapparate is daar nie 'n beduidende verskil op die totale prestasie $(p=0,1008)$ en die emosioneleveranderlikes $(p=0,3489)$ nie, maar daar is wel 'n beduidende verskil wat die situasieveranderlikes ( $p=0,0201$ ) aanbetref. Groep 1 se resultate dui daarop dat hulle beduidend meer baat vind by die dra van gehoorapparate in verskillende luistersituasies as Groep 2 . Hierdie resultate het belangrike implikasies vir die studic, aangesien dit die gebruik van objektiewe metings verder kan ondersteun.

\section{DIE BEJAARDES SE SUBJEKTIEWE EVALUE- 'RING VAN HUL GEHOORPROBLEME TEENOOR DIE OBJEKTIEWE METING VAN HUL GEHOOR. STATUS EN SPRAAKDISKRIMINASIEVERMÖ̈}

Resultate toon daar is ' $n$ beduidende korrelasie tussen die SSI-toets en die aanbieding van die monosillabiese woorde en 'n ipsi-kompeterende boodskap ( $p=0,000$ ); tussen die VSW-toets en die aanbieding van die monosil- labiese woorde en 'n ipsi-kompeterende boodskap ( $p=$ $0,031)$ en tussen die VSW- en SSI-toets $(\mathbf{p}=0,000)$. Die feit dat die toetsresultate korreleer, verhoog die toetsbetroubaarheid en -geldigheid van die studie. Daar is verder 'n beduidende korrelasie tussen die bejaardes se subjektiewe evaluasie van hul gehoorprobleem en die objektiewe evaluasie van hul perifere gehoorstatus ( $p=$ 0,031 ).

Geen beduidende korrelasie bestaan egter tussen die bejaardes se evaluering van hul gehoorprobleme en hul spraakdiskriminasievermoë in verskillende luistersituassies nie. Daar is geen beduidende korrelasie tussen die selfevaluasieskaal en die SSI-toets $(p=0,091)$; die VSW-toets $(\mathrm{p}=0,934)$; en die aanbieding van die monosillabiese woorde met ' $n$ ipsi-kompeterende boodskap $(p=0,2820)$ nie. Geen beduidende korrelasie bestaan ook tussen die bejaardes se evaluering van die baat wat hulle vind by gehoorapparate en hul spraakdiskriminasievermoë in verskillende luistersituasies nic. Daar is dus geen beduidende korrelasie tussen die prestasie met gehoorapparate en die SSI-toets $(\mathrm{p}=0,839)$; die VSW-toets $(\mathrm{p}=$ 0,842 ) en die aanbieding van dic monosillabiese woorde met'n ipsi-kompeterende boodskap $(p=0,724)$ nie.

\section{BESPREKING}

Bejaardes in Groep 2 ervaar beduidend meer spraakdiskriminasieprobleme as die bejaardes in Groep 1, ongeag die feit dat hulle suiwertoondrempels korreleer. Hierdie resultate ondersteun die aanname dat spraakdiskriminasieprobleme 'n nie-perifere basis kan hê en dus nie net verklaarbaar is op grond van suiwertoonresultate nie (Marshall, 1981; Rodriguez, et al., 1990). Spesiale spraaktoetse is in hierdie studie gebruik om sentrale ouditiewe prosessering te ondersoek.

Die SSI-PI-funksie is swakker as die FG-PI-funksie (Willeford, 1985). Tydens die bepaling van die SSI-PIfunksie het die "rollover-" fenomeen by sewe bejaardes van Grocp 2 voorgekom, terwyl hierdie fenomeen by slegs drie bejaardes voorgekom het tydens die bepaling van die FGPI-funksie. Hierdie resultate kan aanduidend wees van aantasting van die ouditiewc senuwee of inperking !van sentrale ouditiewe prosessering (Kaplan, Gladstone \& Katz, 1984).

Die tweede diagnostiese prosedure van die SSI-toets is om die SSI-IKB- en die SSI-KKB-resultate te vergclyk. Met behulp van hierdie prosedure is dit moontlik om 'n sentrale letsel te identifiseer en is dit ook moontlik om te onderskei tussen breinstamletsels en temporale lobletsels (Kaplan, et al., 1984). Groep 2 het beduidend swakker gevaar as Groep 1, maar albei groepe se resultate wyk ook af van die norme wat geld vir volwassenes (Kaplan, et al., 1984). Alhoewel geen bestaande norme beskikbaar is vir bejaardes nie, kan bestaande norme wel sinvol gebruik word om die bejaardes se resultate op 'n kwalitatiewe wyse te beskryf. Afwykende resultate dui dus nie noodwendig op die spesifieke plek van letsel nie, maar kan wel aandui dat ouderdomsverwante veranderinge dic funksie van die sentrale ouditiewe senuweesisteem negatief beïnvloed (Kaplan, et al., 1984; Willeford, 1985).

Verder kom groter IKB-afwykings as KKB-afwykings by beide groepe voor (Kaplan, et al., 1984). Alhoewel hierdie resultate volgens die bestaande' norme op 'n moontlike breinstamletsel kan dui, kan hierdie afleiding nie noodwendig vir die bejaarde populasie gemaak word nie, 
vanweë die kompleksiteit van hul gehoorprobleme. Afleidings kan wel gemaak word dat ouderdomsverwante veranderinge wat voorkom in die sentrale ouditiewe sisteem aanleiding kan gee tot die spesifieke uitvalle soos gemeet op hierdie toets by die bejaarde populasie (Willott, 1991).

Die kwalitatiewe ontleding van die VSW-toetsresultate dui daarop dat bejaardes in beide groepe, meer probleme ondervind in die kompeterende (veral Links-Kompeterende) luistersituasies (Lukas \& Genchur-Lukas, 1985;). Hierdie resultate bevestig probleme in sentrale ouditiewe prosessering, wat onder andere manifesteer as geheue-, lees-, spel- en spraakdiskriminasieprobleme. Die resultate dui verder daarop dat bejaardes nie almal in dieselfde mate probleme met hierdie toetsprosedure ondervind nie. Bejaardes wat dus swakker presteer in hierdie toets, se aantasting van die sentrale senuweesisteem blyk meer uitgesproke te wees as die bejaardes wat minder probleme ondervind.

Tydens die aanbieding van monosillabiese woorde en 'n ipsi-kompeterende boodskap behaal Groep 2 swakker resultate as Groep 1. Hierdie resultate kan ook moontlik toegeskryf word aan die ouderdomsverwante veranderinge in die sentrale ouditiewe senuweesisteem, maar ook aan die degradering van die ouditiewe boodskap deur die gelyktydige aanbieding van 'n ipsi-kompeterende boodskap (Marshall, 1981). Wanneer die ouditiewe sein gekompliseer word en boodskapoortolligheid afneem, ondervind bejaardes problemc met die prosessering van 'n ouditiewe boodskap (Marshall, 1981). Die verskil in resultate van die twee groepe dui ook moontlik daarop dat die plek van aantasting in die ouditiewe sisteem verskil en bevestig ook die groter betrokkenheid van die sentrale ouditiewe senuweesisteem by Groep 2 (Penrod, 1994; Stach, 1994).

Die meting van 'n bejaarde se gehoorverlies is slegs een komponent van die totale intervensieproses (Ventry \& Weinstein, 1982; Taylor, 1993). Gehoortoetse kan wel 'n gehoorverlies kwantifiseer en spraakdiskriminasieproblemc identifiseer, maar dit bied nie voldoende inligting om die effek van die gehoórverlies op die bejaarde se alledaagse funksionering te beskryf nie. Deur gebruik te maak van die bejaardes se subjektiewe evaluasie van hul gehoorprobleme kan waardevolle data ingewin word vir intervensic (Cox, 1996; Ventry \& Weinstein, 1982). Deur gebruik te maak van selfevaluasieskale kan die oudioloog inligting verkry oor die bejaarde se selfpersepsie van sy gehoorgestremdheid, wat deur bepaalde persoonlike, houdings- en situasiefaktore beïnvloed word (Taylor, 1993). Op die langtermyn is dit tog die bejaarde gehoorapparaatgebruiker self wat die sukses van die gehoorapparaatpassing beoordeel (Cox, 1996).

\section{GEVOLGTREKKINGS EN AANBEVELINGS}

Gesien in dic lig van bogenoemde bespreking is dit duidelik dat die intervensie van bejaardes met gehoorprobleme veel meer behels as die evaluering van perifere gehoorstatus. Hierdie populasie het unieke oudiologiese probleme en bepaalde behoeftes en in die lig hiervan kan die volgende gevolgtrekkings en aanbevelings geformuleer word:

Longitudinale navorsing kan gebruik word om die verloop van spraakdiskriminasieprobleme te monitor, en kan dus aanvullend tot die resultate van hierdie studie wees.

Alhoewel norms vir bejaardes nie beskikbaar is nic, beklemtoon hierdie navorsing die gebruik van spesiale spraaktoetse om spraakdiskriminasie ook in komplekse luistersituasie te evalueer. Spesiale toetse moet dus gebruik word om die basiese toetsbattery aan te vul.

Die gebruik van selfevaluasieskale word sterk aanbeveel ten einde 'n holistiese beeld van bejaardes en bejaarde gehoorapparaatgebruikers se ouditiewe funksionering te verkry. Die resultate van die selfevaluasieskale is aanvullend tot die objektiewe toetse wat gedoen word. Deur gebruik te maak van hierdie skale word die suksesvolle intervensie van bejaardes verder verseker. Resente navorsing fokus op die sogenaamde "collaborative" (samewerkende) benadering (Kricos, 1997). Hierdie rehabilitasieprogramme is nie net gerig op die seleksie en passing van gehoorapparate nie, maar fokus ook op ander probleemoplossingstrategieë, soos die aanvaarding van en aanpassing by gehoorverliese, die gebruik van alternatiewe luistersisteme, spraakleesopleiding en die aanleer van ander kommunikasiestrategieë ten einde te verseker dat bejaarde gehoorapparaatgebruikers effektief kan funksioneer in alledaagse luistersituasies (Kricos, 1997).

- Die resultate van hierdie studie kan ook aangewend word om die gehoorprobleme wat bejaardes ondervind, aan die familie van die bejaarde gehoorapparaatgebruiker te verduidelik. Familielede het dikwels beperkte insig in die hantering van en kommunikasie met bejaarde gehoorapparaatgebruikers (Kricos, 1997). Deur ook opleiding en inligting aan hierdie mense te verskaf kan die suksesvolle gebruik van gehoorapparate deur die bejaardes verder verhoog word (Kricos, 1997). Die insluiting van die meting van Ouditief. Ontlokte Potensiale kan ook in toekomstige navorsing gebruik word om die sentrale ouditiewe funksie van bejaardes te ondersoek (Martin \& Cranford, 1989). Resultate wat voorspruit uit sulke studies kan in verband gebring word met bestaande navorsingsdata en dus groter insig verskaf in die ouditiewe probleme van bejaardes. Die gebruik van Ouditief Ontlokte Potensiale, ten einde die sentrale ouditiewe funksie van bejaardes te evalueer, geniet tans beperkte aandag in Suid-Afrika en ook in die bestaande literatuur.

\section{BIBLIOGRAFIE}

Cohen, G. (1987). Speech comprehension in the elderly: The effects of cognitive changes. Brilish Journal of Audiology, 21, 221226.

Cox, R.M. (1996). The Abbreviated Profile of Hearing Aid Benefit (APHAB) - Administration and Application. Phonak Fokus: News, Ideas, High Technology, Acoustics, 21, 2-14.

Folstein, M.F., Folstein, S.E. \& McHugh, P.R. (1975). Mini Mental State Examination: A Practical method for grading the cognitive state of patients for the clinician. Journal of Psychian Research, 12, 189-198.

Goodglass, H. \& Kaplan, E. (1983). The Boston Diagnostic Aphasia Examination. Philadelphia: Lea \& Febiger.

Hull, R.H. (1985). Assisting the Older Client. In Katz, J. (Ed.), Handbook of Clinical Audiology (3rd ed.). Baltimore: Williams \& Wilkins.

Humes, L.E.\& Roberts, L. (1990). Speech-Recognition Difficulties of the Hearing-Impaired Elderly: The Contributions of Audibility. Journal of Speech and Hearing Research, 33, 726735.

Jacobs, C.D., Haasbroek, J.B. \& Theron, S.W. (1992). Effektiewe Navorsing: Navorsingshandleiding vir Tersiere Opleidings- 
inrigtings. Universiteit van Pretoria: Pretoria.

Jerger, J., Jerger, S., Oliver, T. \& Pirozzolo, F. (1989). Speech Understanding in the Elderly. Ear and Hearing, 10(2), 78-89.

Kaplan, H., Gladstone, V.S. \& Katz, J. (1984). Site of Lesion Testing: Audiometric Interpretation, Vol II. Baltimore: University Park Press.

Kricos, P.B. (1997). Audiologic Rehabilitation For The Elderly: A Collaborative Approach. The Hearing Journal, 50(2), 10-19.

Laubscher, A.M.U. \& Tesner, H.E.C. (1966). Enkellettergrepige woordelyste in Afrikaans. Ongepubliseed. Universiteit van Pretoria.

Lemme, M.L. \& Hedberg, N.L. (1988). Auditory Linguistic Processing. In Lass, N.J., McReynolds, L.V., Northern, J.L. \& Yoder, D.E. (Eds.), Handbook of Speech-Language Pathology and Audiology. Toronto: B.C. Decker, Inc.

Lukas, R.A. \& Genchur-Lukas, J. (1985). Spondaic Word Tests In Katz, J. (Ed.), Handbook of Clinical Audiology (3rd ed.). Baltimore: Williams \& Wilkins.

Margolis, R.H. \& Shanks, J.E. (1985). Tympanometry. In Katz, J.(Ed.), Handbook of Clinical Audiometry (3rd ed.). Baltimore: Williams \& Wilkins.

Marshall, L. (1981). Auditory Processing in Aging Listeners. Journal of Speech and Hearing Disorders, 46, 226-240.

Martin, D.R. \& Cranford, J.L. (1989). Evoked Potential Evidence of Reduced Binaural Processing in Elderly Persons. The Hearing Journal, 42(7), 18-23.

Muller, A.M.U. (1981). Die Afrikaanse Sintetiese Sinsidentifikasietoets. Ongepubliseerd. Oudiologie-afdeling: Tygerberg Hospitaal.

Penrod, J.P. (1994). Speech Threshold and Recognition/ Discrimination Testing. In Katz,J. (Ed.), Handbook of Clinical Audiology (4th ed.). Baltimore: Williams \& Wilkins.

Rodriguez, G.P., DiSarno, N.J. \& Hardiman, C.J. (1990). Centra Auditory Processing in Normal-Hearing Elderly Adults.
Audiology, 29, 85-92.

Rosenberg, P.E. (1978). Case History: The First Test. In Katz, J. (Ed.), Handbook

of Clinical Audiology (2nd ed.). Baltimore: Williams \& Wilkins

Stach, B.A. (1994). Hearing Aids and Older People. The Hearing Journal, 47(3), 10-42.

Suid-Afrikaanse Buro vir Standaarde. (1994). Guide to National and International Acoustics, Electro-Acoustics, Vibration and Ultrasonics Publications. Pretoria.

Taylor, K.S. (1993). Self-Perceived and Audiometric Evaluation of Hearing Aid Benefit in the Elderly. Ear and Hearing, 14(6), 390-394.

Theron, S.W. (1995). Persoonlike gesprekke. Departement Menslike Hulpbronbestuur. Universiteit van Pretoria.

Van Wyk, M.E. (1997). Spraakdiskriminasie by bejaarde gehoorapparaatgebruikers. Ongepubliseerde M.Kommunikasiepatologie verhandeling, Universiteit van Pretoria: Pretoria.

Ventry, I.R. \& Weinstein, B.E. (1982). The Hearing Handicap Inventory for the Elderly: a New Tool. Ear and Hearing, 3(3) 128-134

Willeford, J.A. (1985). Sentence Test of Central Auditory Dysfunction. In Katz, J.(Ed.), Handbook of Clinical Audiology (3rd ed.). Baltimore: Williams \& Wilkins.

Willott, J. F. (1991). Aging and the Auditory Systent: Anatomy, Physiology and Psychophysics. San Diego: Singular Publishing Group, Inc.

Working Group on Speech Understanding and Aging. (1988). Speech understanding and aging. Journal of the Acoustical Society of America, 3, 859-895.

Yantis, P.A. (1994). Puretone Air-Conduction Threshold Testing. In Katz, J. (Ed.), Handbook of Clinical Audiology (4th ed.). Baltimore: Williams \& Wilkins. 